\title{
OPUNOMOĆENICI U UPRAVNOM SPORU
}

Prof. dr. sc. Marko Šikić*

Doc. dr. sc. Mateja Held**

\author{
UDK: $347.998 .85: 342.92(497.5)$ \\ https://doi.org/10.30925/zpfsr.41.1.3 \\ Ur.: 24. prosinca 2019. \\ Pr.: 16. ožujka 2020. \\ Izvorni znanstveni rad
}

\begin{abstract}
Sažetak
Nakon donošenja novele Zakona o upravnim sporovima 2014. kojom je čl. 21. dodan stavak 2. sukladno s kojim se u upravnom sporu upućuje na odgovarajuću primjenu odredaba Zakona o parničnom postupku, hrvatski su upravni sudovi zauzeli restriktivan pristup u tumačenju te odredbe kojom su određene kategorije isključene od mogućnosti zastupanja tužitelja i zainteresirane osobe. U radu se problematizira pojam opunomoćenika te se ističu stručnost $i$ kvaliteta kao važne značajke zastupnika općenito, pa tako i opunomoćenika u upravnom sporu. Analiziraju se i poredbena uređenja europskih sustava u predmetnoj materiji. Zauzima se stajalište da je pri tumačenju odredaba o zastupanju nužno voditi računa o posebnostima upravnog spora, ali i o formulaciji odredbe kojom se nedvojbeno ostavlja mogućnost tumačenja jer se upućuje na „odgovarajuću“ primjenu odredbe kojom je uređeno zastupanje u parničnom postupku.
\end{abstract}

Ključne riječi: upravni spor; stranka; zastupanje; opunomoćenik; porezni savjetnik.

\section{1. $U$ VOD}

Upravni je spor najvažniji oblik kontrole rada uprave i najjače jamstvo načela zakonitosti u radu tijela javne uprave. Sudskom kontrolom upravu odvraćamo od nezakonitoga postupanja te uprava prestaje biti „sudac“ u vlastitoj stvari.

Ističe se kako bez kvalitetnog upravnog sudovanja nema i ne može biti kvalitetne javne uprave. Osiguravanje je kvalitetnog upravnog sudovanja conditio sine qua non postojanja kvalitetnoga sustava upravnog prava u nekoj državi. ${ }^{1}$

Uređujući Zakonom o upravnim sporovima² sudsku kontrolu nad upravom hrvatski je zakonodavac propisao da je cilj ZUS-a „osigurati zakonitost i sudsku

* Dr. sc. Marko Šikić, redoviti profesor, Pravni fakultet Sveučilišta u Zagrebu; marko.sikic@, pravo.hr.

** Dr. sc. Mateja Held, docentica, Pravni fakultet Sveučilišta u Zagrebu; mateja.held@pravo.hr

1 V. Frane Staničić, Bosiljka Britvić Vetma i Božidar Horvat, Komentar Zakona o upravnim sporovima (Zagreb: Narodne novine, 2017.), 2.

2 Zakon o upravnim sporovima, Narodne novine, br. 20/10., 143/12., 152/14., 94/16. i 29/17. (u nastavku rada: ZUS). 
zaštitu prava i pravnih interesa fizičkih i pravnih osoba i drugih stranaka povrijeđenih pojedinačnim odlukama ili postupanjem javnopravnih tijela". ${ }^{3}$ Ističe se kako iz navedene odredbe, kao i iz cjelokupne zakonske regulacije, proizlazi da je cilj ZUS-a zaštititi subjektivna prava fizičkih i pravnih osoba, kao i objektivnu zakonitost. Pritom se naglašava kako je u prvom planu zaštita subjektivne, a tek podredno objektivne zakonitosti. $^{4}$

Usporedi li se upravni spor s drugim sudskim postupcima nedvojbeno se može uočiti niz važnih razlika te da upravni spor odlikuju brojne posebnosti. Navedeno proizlazi i iz čvrste povezanosti upravnog postupka i upravnog spora. Tako je u upravnosudskom postupku tužitelj ${ }^{5}$ stranka iz upravnog postupka koja smatra da su joj povrijeđena prava ili pravni interesi donošenjem pojedinačne odluke od strane javnopravnog tijela, postupanjem ili propuštanjem postupanja javnopravnog tijela, nezakonitim sklapanjem, izvršavanjem ili raskidom upravnog ugovora. Tuženik u upravnom sporu uvijek je javnopravno tijelo, i to ono koje je donijelo ili propustilo donijeti upravni akt, postupilo ili propustilo postupiti ili je stranka upravnog ugovora. ${ }^{6}$ Već samo definiranje tužitelja i tuženika pokazuje posebnost procesnoga položaj stranaka u upravnom sporu zbog činjenice da se s jedne strane u sporu javlja javnopravno tijelo, a s druge stranka koja je, u pravilu, fizička ili pravna osoba. U skladu s ciljem ZUS-a, strankama je potrebno osigurati mehanizme kojima će im se omogućiti da najbolje zaštite svoja prava, pritom poštujući načela određena ZUSom. Zbog toga je institut zastupanja stranke iznimno važan u području upravnog spora, gdje o pravima i obvezama stranaka odlučuju upravni sudovi kao nepristrani i neovisni nositelji sudske kontrole nad upravom.

Fokus je rada na opunomoćenicima u upravnom sporu, ${ }^{7}$ no autori $\mathrm{u}$ radu navode i osnovne napomene povezane sa širim pojmom zastupanja u upravnom sporu. Poredbenim prikazom ukazuju na širinu kruga osoba koje se mogu javiti u svojstvu opunomoćenika stranke, posebno u poreznim predmetima. U posebnom

3 V. čl. 2. ZUS-a.

4 V. Dario Đerđa i Marko Šikić, Komentar Zakona o upravnim sporovima (Zagreb: Novi informator, 2012.), 32 i 84 te Staničić, Britvić Vetma i Horvat, Komentar Zakona o upravnim sporovima, 31.

5 V. čl. 17. ZUS-a.

6 V. čl. 18. ZUS-a. ZUS položaj stranke priznaje i zainteresiranoj osobi. Čl. 19. ZUS-a tako propisuje:

„(1) Zainteresirana osoba je svaka osoba kojoj bi poništavanje, izmjena ili donošenje pojedinačne odluke, postupanje ili propuštanje postupanja javnopravnog tijela, odnosno sklapanje, raskid ili izvršavanje upravnog ugovora povrijedilo njezino pravo ili pravni interes.

(2) Zainteresirana osoba je i javnopravno tijelo koje smatra da sudska odluka može imati učinak na prava i pravne interese koje to javnopravno tijelo štiti na temelju zakona.

(3) Sud će po službenoj dužnosti ili na prijedlog stranke pozvati zainteresiranu osobu da sudjeluje u sporu.

(4) Zainteresirana osoba može se uključiti u spor u svakom trenutku.

(5) Sud će bez odgode obavijestiti sve stranke o uključivanju zainteresirane osobe u spor“.

7 U radu se prema tome neće analizirati zastupanje tuženika u upravnom sporu što je, svakako, posebna i vrlo zanimljiva tema. V. o navedenom više u: Staničić, Britvić Vetma i Horvat, Komentar Zakona o upravnim sporovima, 78-81 i Lidija Rostaš Beroš, „Zastupanje stranke u upravnom sporu“, Zbornik Pravnog fakulteta Sveučilišta u Rijeci 37, br. 1 (2016): 740-741. 
je poglavlju istaknuta važnost odgovarajućega zastupanja stranaka za kvalitetu i učinkovitost upravnog spora. Posebna se pozornost pridaje mogućnosti da u svojstvu opunomoćenika u upravnom sporu zastupaju porezni savjetnici. U zaključku rada autori se zalažu za razvoj normativnih rješenja i prakse koji će omogućiti da građane u upravnim sporovima zastupaju osobe koje će svojim stručnim znanjem najbolje znati štiti prava i interese stranaka, ali i objektivnu zakonitost.

Autori se nadaju da će rad doprinijeti širem tumačenju odredbe čl. 21. st. 2. ZUS-a, što je iznimno važno za očuvanje objektivne zakonitosti i vladavine prava, ali i zaštite subjektivnih prava i pravnih interesa pojedinaca u postupcima pred upravnim sudovima.

\section{OPĆENITO O ZASTUPANJU TUŽITELJA (I ZAINTERESIRANE OSOBE) U UPRAVNOM SPORU}

Institut zastupanja poznat je i primjenjivan još u rimskom pravu ${ }^{8}$ sukladno s kojim je posredno zastupanje imalo veću važnost. ${ }^{9}$ Današnji sustavi primat daju neposrednom zastupanju stranaka, iako u različitim državama postoje razni oblici zastupanja, a sukladno s tim postoji i bogata terminologija te razni uvjeti koji se postavljaju pred osobu koja želi biti opunomoćenik stranke u nekom sudskom postupku.

I u upravnom sporu vrijede principi stranačke autonomije i dispozitivnosti, tako da tužitelji i zainteresirane osobe načelno mogu i samostalno poduzimati radnje u sporu. ${ }^{10}$ Međutim, u određenim slučajevima tužitelje mogu zastupati zakonski zastupnici ili se tužitelji mogu odlučiti da ih u sporu zastupaju opunomoćenici. ${ }^{11}$

8 O opširnom prikazu razvoja zastupanja u rimskom pravu - primarno prokuratora kojem je temeljna funkcija bila zastupanje stranaka pred sudom, bilo uz njihovu prisutnost ili bez nje, te advokata koji je pružao svoju stručnu pomoć uz prisutnost stranke te o detaljnijem pojašnjenju samih pojmova procurator, procurator ad litem, procurator omnium bonorum, advocatus, advocatus sive iuris peritus v. u: Henrik-Riko Held, ,, Procuratoris revocatio u pravu Tripartita “, Zbornik Pravnog fakulteta u Zagrebu 68, br. 5-6 (2018.): 832-834. Held naglašava da je konceptualno razlikovanje prokuratora i advokata vidljivo i danas u poredbenom pravu. Primjerice u talijanskom pravu razlikuju se avvocato i procuratore, $\mathrm{u}$ francuskom avocat $\mathrm{i}$ avoué, a u engleskom, uz određene razlike u odnosu na kontinentalna prava, barrister i solicitor. Navedeno razlikovanje danas postoji u suvremenom kanonskom pravu (Held, „Procuratoris revocatio u pravu Tripartita “, 835-837). Kratko o razvoju odvjetništva v. u: Alan Uzelac, „Obvezatno odvjetničko zastupanje? Prilog diskusiji o reformi hrvatskog parničnog prava. Teorijski i komparativni aspekti“, Pravo u gospodarstvu 37, br. 2 (1998.), 167.

9 Marijan Horvat, Rimsko pravo (Zagreb: Pravni fakultet, 2002.), 270.

10 V. čl. 20. ZUS-a. Pravo stranke da samostalno (tj. neposredno, bez punomoćnika) nastupa u građanskom postupku u teoriji nazivano je još i postulacijskom sposobnošću. Ovaj pojam treba razlikovati od parnične sposobnosti, kao sposobnosti da se vlastitim izjavama volje (bilo osobno, bilo putem treće osobe) u parnici proizvode procesni učinci. V. Siniša Triva, Velimir Belajec i Mihajlo Dika, Građansko parnično procesno pravo (Zagreb: Narodne novine, 1986.), § 66/1, Siniša Triva, Rječnik Građanskog procesnog prava (Zagreb: Informator, 1968.), 244 i Uzelac, Obvezatno odvjetničko zastupanje? Prilog diskusiji o reformi hrvatskog parničnog prava. Teorijski i komparativni aspekti, 150.

11 Prema važećoj terminologiji, sukladno sa ZUS-om, u ovom se radu koristi pojam 
ZUS je u svom prvotnom tekstu iz 2010. ${ }^{12}$ predviđao da tužitelja i zainteresirane osobe u upravnom sporu može zastupati zakonski zastupnik, zajednički predstavnik i opunomoćenik. ${ }^{13} \mathrm{~S}$ obzirom na navedenu odredbu istaknuto je da opunomoćenik u upravnom sporu može biti svaka osoba koja je potpuno poslovno sposobna osim osobe koja se bavi nadripisarstvom. ${ }^{14}$ Navedeno je stajalište razvila i sudska praksa.

Međutim, novelom ZUS-a iz 2014. čl. 21. dodan je st. 2. koji glasi:

$\mathrm{Na}$ pitanja valjanosti zastupanja koja nisu uređena ovim Zakonom na odgovarajući način se primjenjuju odredbe kojima je uređeno zastupanje u parničnom postupku.

Takva je regulacija u praksi dovela do shvaćanja da u upravnom sporu tužitelja i zainteresiranu stranku ne mogu zastupati porezni savjetnici. Visoki je upravni sud tako u Rješenju Usž-76/15-2 od 26. veljače 2015. potvrdio pravilnost postupanja Upravnog suda u Rijeci koji je Rješenjem 5 UsI-730/13-5 od 16. siječnja 2015. ${ }^{15}$ uskratio poreznom savjetniku mogućnost zastupanja u upravnom sporu, a to je svoje stajalište temeljio na izmjenama ZUS-a iz 2014., kojima se podredno primjenjuje čl. 89. a ZPP-a.

\section{OPUNOMOĆENICI U UPRAVNOM SPORU U POREDBENOM PRAVU}

Austrija je primjer zemlje koja ima specijalizirano upravno sudovanje, ${ }^{16}$ a ujedno, uz upravne sudove postoje i sudovi koji presuđuju isključivo u financijskim predmetima. Dvije vrste poreznih sudova presuđuju u poreznim predmetima. $\mathrm{O}$ lokalnim ili provincijskim porezima odlučuje devet upravnih sudova koji su ustrojeni

„opunomoćenik“. Važeći Zakon o parničnom postupku, Narodne novine, br. 53/91., 91/92., 58/93., 112/99., 88/01., 117/03, 88/05., 02/07., 84/08., 96/08., 123/08., 57/11., 148/11., 25/13., 89/14., 70/19. (u nastavku rada: ZPP) koristi pojam punomoćnik. U dijelovima rada u kojima se analiziraju pojedine zakonske odredbe koje su odlučne za zastupanje u upravnom sporu, sukladno sa ZUS-om koristit će se naziv opunomoćenik, odnosno punomoćnik sukladno s važećim zakonskim tekstom ZPP-a.

12 Zakon o upravnim sporovima, Narodne novine, br. 20/10. (u nastavku rada: ZUS-2010).

13 V. čl. 21. ZUS-a-2010.

14 V. Đerđa i Šikić, Komentar Zakona o upravnim sporovima, 151. Takvo je tumačenje povezano s odredbom čl. 36. st. 1. Zakona o općem upravnom postupku, Narodne novine, br. 47/09. (u nastavku rada: ZUP), koja propisuje da stranka, odnosno njezin zakonski zastupnik može za opunomoćenika odrediti odvjetnika, odvjetnički ured ili drugu pravnu osobu koja na temelju zakona može zastupati stranku, odnosno svaku drugu potpuno poslovno sposobno osobu, osim one koja se bavi nadripisarstvom.

Nadripisarstvo je kazneno djelo predviđeno Kaznenim zakonom, Narodne novine, br. 125/11., 144/12., 56/15., 61/15., 101/17., 118/18. Članak 313. Kaznenog zakona propisuje:

„Tko se neovlašteno bavi pružanjem pravne pomoći uz naplatu, kaznit će se kaznom zatvora do šest mjeseci“".

15 Tekst Rješenja Visokog upravnog suda Republike Hrvatske, pristup 20. studeni 2019., https:// sudskapraksa.csp.vsrh.hr.

16 O ustrojstvu upravnih sudova u Austriji v. u: Mateja Held, „Neka važna pitanja uređenja i reformi upravnog sudovanja u europskim zemljama“, Zbornik Pravnog fakulteta u Zagrebu 69, br. 4 (2019.): 570-572. 
nakon reforme ${ }^{17}$ sustava upravnih sudova iz $2013 .{ }^{18} \mathrm{O}$ saveznim porezima odlučuje Savezni porezni sud. ${ }^{19}$ Kod odabira opunomoćenika u predmetima pred Saveznim financijskim sudom (njem. Bundesfinanzgericht) stranke imaju nekoliko mogućnosti. One mogu samostalno sudjelovati u upravnom sporu ili angažirati odvjetnika. Stranke mogu, s obzirom na specifičnost predmetne materije odabrati i da ih zastupa registrirani porezni savjetnik ili ovlašteni javni računovođa. ${ }^{20}$ Zakon o Vrhovnom upravnom sudu u $\S 23$. (1) propisuje da stranke u postupcima pred Vrhovnim upravnim sudom može zastupati i porezni savjetnik ili računovođa. ${ }^{21}$

U Francuskoj ne postoje posebni porezni sudovi te se postupak vezan za poreznu materiju može pojaviti pred upravnim, građanskim ili kaznenim sudom, ovisno o porezu ili o kazni koja se ima primijeniti. ${ }^{22}$ Upravnosudski postupak vodi se na tri razine. Na prvoj su upravni sudovi ${ }^{23}$ i sudovi prvog stupnja, na drugoj su upravni prizivni sudovi ${ }^{24}$ i žalbeni sudovi, a na trećoj najvišoj razini su Državni savjet ${ }^{25}$ i Kasacijski sud, koji odlučuju samo o pitanjima prava, a ne i o činjenicama. ${ }^{26,27}$

Pred sudovima prvog stupnja nije obvezatno zastupanje. Na drugom je stupnju obvezatno zastupanje od strane odvjetnika. Na trećem stupnju poreznog obveznika

17 Poticaj za provođenje reforme bili su standardi Europskog suda za ljudska prava i temeljne slobodne, ponajprije zahtjev za dvostupanjskim uređenjem upravnog sudovanja te čl. 47. Povelje o temeljnim pravima Europske unije (O reformi ustrojstva upravnih sudova u Austriji više u: Held, Neka važna pitanja uređenja i reformi upravnog sudovanja u europskim zemljama, 569-572. O razlozima osnivanja nezavisnih tribunala i usklađivanju s EKLJP-om, posebno čl. 5. i 6. vidi u: Manfred Stelzer, Constitution of the Republic of Austria: A Contextual Analysis, (Oregon; Oxford and Portland: Hart Publishing, 2011.), 184-186.

18 U Austriji je usvojen tzv. 9+2 model s devet upravnih sudova na razini zemalja (Länder) te dva savezna upravna suda jedan za upravne stvari, a drugi za porezne stvari (Martin Köhler, „The Reform of The Administrative Jurisdiction in Austria - Theoretical Background and Main Features od The System", Public Security and Public Order 14, br. 4 (2015.): 31.

19 Gerald Schanchner, Kornelia Wittmann i Nicolas D. Wolski, „Austria“, u: Tax Disputes and Litigation Review, ur. Simon Whithead (London: Law Business Research, 2019.), 9.

20 Schanchner, Wittmann i Wolski, Austria, 7.

21 Verwaltungsgerichtshofgesetz 1985, BGB1. Nr. 10/1985, BGB1. I Nr. 194/1999, BGB1. I Nr. 104/2019.

22 Phillipe Derouin, „France“, u: Tax Disputes and Litigation Review, ed. Simon Whithead (London: Law Business Research, 2019.), 93.

23 Upravni su sudovi osnovani ukazom od 30. rujna 1953. (Décret n 53-934 du 30 septembre 1953 portant réforme du contentieux administratif, Journaux Officiels de la République Française (JORF) od 1. listopada 1953.).

24 Žalbeni ili prizivni sudovi osnovani su zakonom od 31. prosinca 1987. Jedan je od ciljeva njihova osnivanja bio profesionalizacija upravnog sudovanja (Frédéric Colin, Marie-Laure Messe, L'essentiel du contentieux administratif (Pariz: Gaulino, Pariz, 2014.), 25.

25 O Državnom savjetu više v. u: Marc Gjidara, „Državni savjet u francuskom pravnom sustavu “, u: Zbornik radova Hrvatsko-francuskog pravnog simpozija, ur. Damir Aviani (Split: Sveučilište u Splitu, 2007.), 8; Bosiljka Britvić Vetma, „Ustroj i nadležnost upravnih sudova“, Zbornik Pravnog fakulteta Sveučilišta u Rijeci 33, br. 1 (2012.): 391; Jean-Marc Sauvé, „Rad i utjecaj francuskog Državnog savjeta“, Zbornik radova Pravnog fakulteta u Splitu 45, br. 1 (2008.): 1.

26 Derouin, France, 94.

27 Općenito o upravnim i žalbenim sudovima te o Državnom savjetu v. i: Hugo Flavier i Charles, Forger, „Administrative justice in France. Between singularity and classicism“, Brics Law Journal 3, br. 2 (2016.): 84-87. 
mora zastupati odvjetnik (ima ih 60), koji je na listi odvjetnika koji djeluju pred Državnim savjetom i kasacijskim sudom. Takvo se ograničenje ne primjenjuje pred Ustavnim vijećem ili pred Sudom Europske unije, gdje svaki registrirani odvjetnik može pomagati strankama, a vladu u tim postupcima zastupa vladin zastupnik. ${ }^{28}$

Njemački specijalizirani sudovi dijele se na radne, upravne, socijalne i porezne sudove. Ustrojstvo njemačkih upravnih sudova je trostupanjsko, ${ }^{29}$ a detaljnije je uređeno Uredbom o upravnim sudovima (Verwaltungsgerichtsordnung, VwGO). ${ }^{30}$ Porezni (financijski) sudovi su ustrojeni u dva stupnja. Prvi su stupanj regionalni porezni (financijski) sudovi (njih 18), ${ }^{31}$ a drugi je Savezni porezni (financijski) sud. ${ }^{32}$ Savezni porezni sud ustrojen je sukladno s čl. 95. Temeljnog zakona i njegovo je sjedište u Münchenu. Glavna mu je zadaća osigurati dosljednost u primjeni i izvršavanju prava kroz njegovu interpretaciju. Savezni porezni sud doprinosi razvoju poreznog prava u skladu s Temeljnim zakonom. ${ }^{33}$

U Njemačkoj ne postoji zahtjev za obveznim zastupanjem pred poreznim sudovima, međutim, poreznim obveznicima dopušteno je imati zastupnika koji može biti odvjetnik, porezni savjetnik, računovođa i sl. ${ }^{34}$ Međutim, kada stranka u svom predmetu dođe do Saveznog poreznog suda ona mora obvezatno imati zastupnika., Tako primjerice porezni obveznik može uložiti pravni lijek putem zastupnika, koji je sukladno sa zakonom o poreznom savjetništvu ovlašten postupati u pitanjima povezanim s porezima. ${ }^{35}$ Smatra se da je razina uspješnosti pred poreznim sudovima prvog stupnja posljedica neangažiranja odvjetnika ili kvalificiranoga poreznog savjetnika. ${ }^{36}$

Estonija ima trostupanjsko uređenje upravnih sudova. Na prvom su stupnju ustrojeni upravni i pokrajinski (county) sudovi, na drugom su okružni sudovi, a na trećem je Vrhovni sud Estonije. ${ }^{37}$ Upravni akti podliježu kontroli redovnih (pokrajinskih) sudova i specijaliziranih upravnih sudova. Kod redovnih sudova postoje posebna vijeća koja se bave upravnim predmetima. Dva su upravna suda prvog stupnja sa sjedištem u Tallinnu i Tartuu, sa sudskim ispostavama (engl. courthouses)

28 Derouin, France, 94.

29 V. Savezni upravni sud, pristup 2. prosinca 2019., https://www.bverwg.de/en/rechtsprechung/ verwaltungsgerichtsbarkeit/aufbau-der-verwaltungsgerichtsbarkeit.

30 Verwaltungsgerichtsordnung od 21. siječnja 1960. u verziji objavljenoj u ožujku 1991. (BGB1. I S. 686), sa zadnjom izmjenom od 12. srpnja 2018. (BGB1. I S. 1151).

31 Axel Cordewener i Michael Hendricks „Germany“ u. Tax Disputes and Litigation Review, ed. Simon Whithead (London: Law Business Research, 2019.), 102.

32 Cordewener i Hendricks, Germany, 101.

33 V. Savezni financijski sud, pristup 21. studenoga 2019., https://www.bundesfinanzhof.de/ content/information-english?tid=42.

34 Thomas Busching, Tax Controversy in Germany, pristup 21. studenoga 2019., https://www. lexology.com/library/detail.aspx?g=0cda47f8-d6f0-458b-b459-e662d797fc93.

35 V. Savezni financijski sud, pristup 21. studeni 2019., https://www.bundesfinanzhof.de/content/ information-english?tid $=42$.

36 Cordewener i Hendricks, Germany, 102.

37 Administrative Justice in Estonia - Report for Estonia, 1. Dostupno na: http://www.aca-europe. eu/en/eurtour/i/countries/estonia/estonia_en.pdf, pristup 9. prosinca 2019. 
u ostalim gradovima. ${ }^{38}$ Odluke tih sudova nadziru upravni odjeli žalbenih sudova (okružnih sudova). ${ }^{39}$ Upravni akt može biti predmet nadzora i pred Vrhovnim sudom u upravnom odjelu koji sudi u sastavu od najmanje tri suca. ${ }^{40}$ Nadležnost upravnih sudova uređena je u § 37., Zakona o postupku pred upravnim sudom. ${ }^{41}$

Treći dio Zakona o postupku pred upravnim sudom regulira, uz zastupanje, i savjetovanje u upravnom sporu. Osim ako zakon ne propisuje drukčije, stranka se u upravnom sporu može zastupati samostalno ili putem zastupnika. ${ }^{42}$ Zakon o postupku pred upravnim sudom, slično kao i hrvatski ZUS, predviđa primjenu Zakona o parničnom postupku. ${ }^{43}$ Međutim, Zakonom o postupku pred upravnim sudom izrijekom je navedeno tko sve može zastupati stranku u upravnom sporu. Sukladno s $§ 32$. Zakona o postupku pred upravnim sudom ovlašteni zastupnik može biti odvjetnik, osoba koja ima više pravno obrazovanje. ${ }^{44} \mathrm{U}$ poreznim predmetima to može biti konzultant iz područja poreza ili računovodstva ${ }^{45}$ koji ima više ekonomsko obrazovanje. ${ }^{46} \mathrm{U}$ predmetima koji se tiču komercijalnih aktivnosti, stranku može zastupati prokurist stranke, dok službenik ili strankin zaposlenik može stranku zastupati ako sud smatra da posjeduje takva znanja i iskustvo koje je dostatno za zastupanje stranke. ${ }^{47}$

Sudska zaštita protiv upravnih akata zajamčena je u grčkom Ustavu u čl. 20 st. 1. Velika reforma upravnog sudovanja koja se u Grčkoj dogodila 2010, rezultirala je dvostupanjskim ustrojem sudova (prvi i žalbeni stupanj ${ }^{48}$ ). ${ }^{49}$ Poseban je fokus bio upravo na poreznim stvarima. U Grčkoj postoji institut obveznog zastupanja od strane odvjetnika, osim u slučajevima koji ne premašuju iznos od 1500 eura ili u slučajevima socijalnih pitanja poput mirovina. ${ }^{50} \mathrm{U}$ Nizozemskoj se stranka u postupcima može

38 Upravni sud u Tallinnu ima dvije sudske ispostave - Tallina koja broji 16 sudaca i Pärnu s dva suca. Upravni sud u Tartuu ima ispostavu sa šest sudaca, a ispostava u gradu Jõhvi sastoji se od tri suca (pristup 22. studeni 2019., https://www.lawyersestonia.com/a-guide-to-estoniancourts).

39 Lawyers Estonia, pristup 22. studeni 2019., https://www.lawyersestonia.com/a-guide-toestonian-courts.

40 ACA, Estonia, str. 2.

41 Zakon o postupku pred upravnim sudom, 2012., pristup 22. studenoga 2019., https://www. riigiteataja.ee/en/eli/527012014001/consolide.

42 Angažiranje zastupnika ne sprječava stranku da se samostalno zastupa. Isto tako, samostalno zastupanje ne sprječava sudjelovanje zastupnika u sporu (§ 31. Zakona o postupku pred upravnim sudom).

43 V. § 31. st. 4. Zakona o postupku pred upravnim sudom.

44 Osoba s višim pravnim obrazovanjem ne može zastupati stranku pred Vrhovnim sudom sukladno s § 32. st. 2. Zakona o postupku pred upravnim sudom.

45 Konzultant iz područja poreza ili računovodstva ne može zastupati stranku pred Vrhovnim sudom sukladno s $\S 32$. st. 2. Zakona o postupku pred upravnim sudom.

$46 \mathrm{O}$ potrebnom stupnju obrazovanja koje se smatra višim pravnim i višim ekonomskim obrazovanjem v. § 32. st. 3. Zakona o sudskom postupku pred upravnim sudovima.

47 Za ostale slučajeve zastupanja v. § 32. st. 6.-8. Zakona o postupku pred upravnim sudovima.

48 Ioannis Stavropoulus, „Greece“, u: Tax Disputes and Litigation Review, ed. Simon Whithead (London: Law Business Research, 2019.), 118.

49 Stavropoulus, Greece, 116.

50 Vassilis Androulakis, Administrative Justice in Europe - Greek Report, pristup 28. studenoga 
zastupati sama, odnosno nije obvezatno da ju zastupa odvjetnik ili porezni savjetnik. ${ }^{51}$ Prvostupanjski upravni sud u Poljskoj je Sud vojvodstva. Žalbeni sud je Vrhovni upravni sud. Žalbu Vrhovnom upravnom sudu može podnijeti jedino odvjetnik ili porezni savjetnik. ${ }^{52} \mathrm{U}$ Belgiji nema obvezatnog zastupanja pred sudovima u poreznim stvarima. ${ }^{53} \mathrm{U}$ Danskoj ne postoji posebni sud za poreze, tako da će se spor voditi pred sudom opće nadležnosti u skladu s postupovnim pravilima građanskog prava, ali s potrebnim prilagodbama. ${ }^{54} \mathrm{U}$ Finskoj se sudovi dijele na sudove koji se bave kaznenim pravom, na sudove koji odlučuju u građanskim predmetima te na sudove koji odlučuju u upravnim predmetima, poput primjerice sudova nadležnih za rješavanje u poreznim stvarima. ${ }^{55}$

\section{VAŽNOST KVALITETNOGA ZASTUPANJA U UČINKOVITOM UPRAVNOM SPORU}

Kako je u uvodnom dijelu rada istaknuto, novelom je ZUS-a iz 2014., između ostaloga, određeno da će se na pitanja valjanosti zastupanja tužitelja i zainteresirane osobe, a koja nisu uređena ZUS-om odgovarajući primjenjivati odredbe kojima je uređeno zastupanje u parničnom postupku. S obzirom na to da čl. 89a ZPP-a određuje da stranku kao punomoćnik može zastupati samo odvjetnik, ako zakonom nije drukčije određeno, Rješenjem Usž-76/15-2 od 26. veljače 2015. Visokog upravnog suda Republike Hrvatske zauzeto je ranije spomenuto shvaćanje, prema kojem je poreznim savjetnicima uskraćena mogućnost zastupanja stranaka u svojstvu opunomoćenika u upravnom sporu. Iako se iz rješenja ne može nepobitno zaključiti da Visoki upravni sud Republike Hrvatske smatra da uslugu zastupanja u svojstvu opunomoćenika u upravnom sporu mogu pružati samo odvjetnici, takvo je tumačenje svakako vrlo moguće. ${ }^{56}$

S obzirom na to da je mišljenje autora da je navedeno shvaćanje previše restriktivno, pokušat će objasniti i razloge svoga stajališta.

Autori ističu da ZPP punomoćnicima u parničnom postupku posvećuje svoju petu glavu koja broji 16 članaka, a punomoćnicima se indirektnije bavi i u nizu svojih

2019., http://www.aca-europe.eu/en/eurtour/i/countries/greece/greece_en.pdf.

51 Paul Kraan, „Netherlands“, u: Tax Disputes and Litigation Review, ed. Simon Whithead (London: Law Business Research, 2019.), 211.

52 Slawomir Luczak i Karolina Gotfryd, „Poland“, u: Tax Disputes and Litigation Review, ed. Simon Whithead (London: Law Business Research, 2019.), 265.

53 Caroline P Docclo, „Belgium“, u: Tax Disputes and Litigation Review, ed. Simon Whithead (London: Law Business Research, 2019.), 15 i 22.

54 Jakob Skaadstrup Andersen, „Denmark“, u: Tax Disputes and Litigation Review, ed. Simon Whithead (London: Law Business Research, 2019.), 65.

55 Jouni Weckström, „Finland“, u: Tax Disputes and Litigation Review, ed. Simon Whithead (London: Law Business Research, 2019.), 77. U finskom Zakonu o upravnim sporovima navodi se samo zastupnik, bez detaljnijeg ulaženja u materiju (v. Administrative Judicial Procedure Act (586/1996; s izmjenama 891/2015, pristup 9. prosinca 2019., https://www.finlex.fi/en/laki/ kaannokset/1996/en19960586_20150891.pdf).

56 Autori napominju kako pri pisanju rada nisu imali uvid u rješenje Upravnog suda u Rijeci 5 Usl-730/13-5 od 16. siječnja 2015., budući da ono nije javno objavljeno. 
drugih odredbi. Pri zauzimanju stajališta o uskraćivanju mogućnosti zastupanja od strane poreznih savjetnika kao opunomoćenika u upravnom sporu vjerojatno je uzet $\mathrm{u}$ obzir samo čl. 89. a st. 1. ZPP-a koji određuje:

Stranku kao punomoćnik može zastupati samo odvjetnik, ako zakonom nije drugačije određeno.

Međutim, i iz citirane odredbe tako proizlazi da zakonodavac ostavlja mogućnost da stranku u parničnim postupcima zastupaju i osobe koje nisu odvjetnici, ako je tako propisano posebnim zakonom..$^{57}$ Nadalje, isti članak u stavcima 2. i 3. normira da stranku kao punomoćnik može zastupati i osoba koja je s njom u radnom odnosu, ako je potpuno poslovno sposobna kao i srodnik po krvi u pravoj liniji, brat, sestra ili bračni drug, ako je potpuno poslovno sposoban i ako se ne bavi nadripisarstvom. Također, čl. 434. a ZPP-a određuje da u postupcima iz radnih odnosa radnika kao punomoćnik može zastupati osoba koja je u radnom odnosu u sindikatu, čiji je on član ili u udruzi sindikata u koju je udružen sindikat čiji je on član, kao i da poslodavca može u istoj vrsti postupaka kao punomoćnik zastupati osoba koja je u radnom odnosu u udruzi poslodavaca čiji je on član ili u udruzi poslodavaca više razine u koju je udružena udruga poslodavaca čije je on član.

Prema tome, očito je da zakonodavac, iako je zauzeo restriktivno stajalište ${ }^{58}$ u pogledu zastupanja stranaka od strane punomoćnika u parničnom postupku, ne ograničava osobe punomoćnika samo na odvjetnike, već omogućuje i drugim osobama da u toj ulozi sudjeluju u parničnom postupku.

Nadalje, autori naglašavaju i upozoravaju na brojne i očite razlike između upravnog spora i parničnog postupka te da ni uloge parničnih i upravnih sudova nisu istovjetne. Stoga su, u situacijama kada zakonodavac upućuje na „odgovarajuću“

57 To se u određenim posebnim zakonima i čini. Tako Zakona o javnom bilježništvu, Narodne novine, br. 78/93., 29/94., 162/98., 16/07., 75/09. i 120/16., propisuje:

„(1) Javni bilježnik je ovlašten zastupati stranke u upravnim stvarima pred sudovima i drugim javnim tijelima ako su te stvari u neposrednoj vezi s kojom njegovom ispravom.

(2) U slučajevima iz stavka 1. ovoga članka javni bilježnik ima prava i dužnosti odvjetnika.“ (čl. 4.) i

„Ako javni bilježnik zastupa kao punomoćnik stranke u postupku pred sudom ili drugim tijelom, ima pravo na nagradu i naknadu troškova po odvjetničkoj tarifi“ (čl. 167.).

58 O restriktivnom i permisivnom pristupu zastupanju v. opširnije u: Uzelac, Obvezatno odvjetničko zastupanje? Prilog diskusiji o reformi hrvatskog parničnog prava. Teorijski i komparativni aspekti, str. 158. Uzelac ističe da se podjela na permisivne i restriktivne sustave može uzeti u obzir tek orijentacijski, jer razni nacionalni sustavi poznaju različita rješenja, koja dijelom potpadaju pod jedan, dijelom pod drugi model ili se nalaze u sredini raspona koje omeđuju dvije krajnosti. Iako modelski postoje određene razlike između različitih pravnih tradicija, Uzelac napominje da je teško vući razgraničenja prema tradicijskim ili zemljopisnim granicama. Bitne su razlike i unutar zemalja europsko-kontinentalnog, odnosno angloameričkoga pravnog kruga, pa i unutar pojedinih vrsta postupaka u tim zemljama. Također, ističe i „da su malobrojni i globalno nereprezentativni ekstremno permisivni i ekstremno restriktivni slučajevi, a da se velika većina civiliziranih država svijeta nalazi negdje po sredini između dvije krajnosti, ostavljajući neke aspekte forenzičke djelatnosti slobodnoj stranačkoj inicijativi, a rezervirajući neke radnje za posebno kvalificirane i/ili licencirane stranačke punomoćnike" (Uzelac, Obvezatno odvjetničko zastupanje? Prilog diskusiji o reformi hrvatskog parničnog prava. Teorijski i komparativni aspekti, 153.). 
primjenu odredbi parničnog postupka, upravni sudovi dužni obvezni uvažiti navedene činjenice te upravo na taj način - odgovarajući - u upravnom sporu primjenjivati pravila parničnog postupka. ${ }^{59}$

S obzirom na to da ZUS nakon noveliranja iz 2014. upućuje na odgovarajuću primjenu odredbi parničnog postupka u pitanjima valjanosti zastupanja, očito je da je namjera zakonodavca bila osigurati odgovarajuće korištenje brojnih i detaljnih odredbi ZPP-a kojima je uređeno pitanje punomoćnika i tako obogatiti i omogućiti što kvalitetnije vođenje upravnih sporova. Naime, očita je podnormiranost ZUS-a u navedenom pitanju - zastupanju tužitelja i zainteresirane osobe posvećen je samo jedan jedini članak, a ako se izuzme novelom dodani stavak, zapravo samo jedan stavak. Prema tome, da je jedina namjera zakonodavca bila odrediti da opunomoćenici tužitelja i zainteresiranih osoba u upravnom sporu budu samo odvjetnici i/ili neke druge kategorije osoba, mogao je to, upravo takvom ili sličnom formulacijom, izričito odrediti, a ne upućivati općenito na odgovarajuću primjenu odredbi parničnog postupka.

Vezano, nadalje, za naznačenu potrebu odgovarajuće primjene odredbi parničnog postupka u svjetlu posebnosti upravnog spora nužno je naglasiti nekoliko činjenica. Tako, najprije, ističemo da je cjelokupni upravni spor potrebno voditi sukladno s ciljem ZUS-a i njegovim načelima. Kako je već ranije u radu istaknuto, cilj ZUS-a je određen i kao zaštita objektivne zakonitosti i kao sudska zaštita prava i pravnih interesa fizičkih i pravnih osoba. Zapravo je cilju upravnog spora podređena cjelokupna regulacija vođenja upravnog spora, legitimacija tužitelja i zainteresirane osobe, tijek upravnosudskog postupka, utvrđivanje činjeničnog stanja te izvršenje sudskih odluka. ${ }^{60}$ Objektivno se pravo u pravilu štiti odlučivanjem o subjektivnim pravima tužitelja, dok se objektivna zakonitost štiti u tzv. objektivnom upravnom sporu u kojem Visoki upravni sud Republike Hrvatske odlučuje o ocjeni zakonitosti općih akta. ${ }^{61}$ Zadaća zastupnika u upravnom sporu, prema tome, nije isključivo u brizi oko zaštite subjektivnih prava stranaka, pa tako niti opunomoćenici ne sudjeluju u upravnom sporu s isključivom svrhom brige oko zaštite prava svojih klijenata, tužitelja u upravnom sporu. Njihova je uloga puno šira jer se njihovim sudjelovanjem u upravnom sporu postiže javnopravna svrha i kvalitetnija zaštita objektivnog prava. ${ }^{62}$

59 V. Odluku Ustavnog suda Republike Hrvatske, U-III/1/2009 od 3. studenog 2010.

60 V. Odluku i Rješenje Ustavnog suda Republike Hrvatske, U-I-2573/2012 od 27. rujna 2016. Maganić i Đerđa kao javnopravne elemente upravnog spora navode predmet upravnog spora, određenost tuženika u upravnom spor, vezanost upravnog suda tužbenim zahtjevom, utvrđivanje istine u sporu, svrhu usmene rasprave te vraćanje predmeta na ponovo rješavanje javnopravnom tijelu (Aleksandra Maganić i Dario Đerđa, Primjena odredbi parničnog postupka u upravnom sporu (Zagreb: Pravosudna akademija, 2017.), 8-18).

61 Više o objektivnom upravnom sporu u Hrvatskoj v. Mateja Crnković, Objektivni upravni spor u hrvatskom i poredbenom pravu, doktorska disertacija (Zagreb: Pravni fakultet Sveučilišta u Zagrebu, 2015.), 159-257.

62 I Uzelac ističe kako i parnični postupak nije jedino u funkciji zaštite individualnih, privatnih interesa. Navodi kako posebno u europsko-kontinentalnom kulturnom krugu nije sporno da bi suvremeno procesno pravo trebalo, uz zaštitu privatnih interesa ostvariti i određenu socijalnu funkciju te da bi čak i bez ideje o socijalnoj jednakosti, čisti koncept proceduralne pravičnosti i fair postupka nalagao da se pomogne stranci koja nije u stanju učinkovito braniti svoja prava. 
Važno je naglasiti i da se u upravnim sporovima (te i u upravnim postupcima koji im prethode) u osnovi često nalaze upravne stvari vrlo stručne i tehničke prirode te stranka može imati mnogo veće koristi da kao opunomoćenika angažira osobu sa stručnim specifičnim znanjem (npr. porezne savjetnike, inženjere tehničkih, prirodnih i srodnih znanosti i sl.). Navedene će osobe često u upravnom sporu u cjelini njezine interese zastupati i bolje nego što bi to radili opunomoćenici koji nisu specijalizirani za takva stručna pitanja - npr. odvjetnici. Kako smo to ranije u radu i naveli u upravnom se postupku strankama omogućuju da kao opunomoćenika, osim odvjetnika, angažiraju i bilo koju drugu potpuno poslovno sposobnu osobu, osim one koja se bavi nadripisarstvom (v. čl. 36. st. 1. ZUP-a). Zar je zaista za sudjelovanje u upravnom sporu stručno pravničko znanje u tolikoj mjeri potrebnije i dominantnije da bi zahtijevalo isključivanje mogućnosti zastupanja stranaka u ulozi opunomoćenika sve struke osim pravničke? Argumentum ad comparationis, autori ističu kako u poredbenom pravu, u sustavima koji su znatno utjecali na razvoj hrvatskoga upravnog prava, poput austrijskog ili njemačkog te u velikom sustavu poput poljskog, ali i manjem koji se može pohvaliti vrlo visokom učinkovitošću sudstva poput estonskoga, ${ }^{63}$ nije zauzet restriktivan pristup kod zastupanja stranaka u upravnom sporu, a napose je to vidljivo kod određivanja opunomoćenika u financijskim predmetima.

Prednosti koje nudi kvalitetno zastupanje stranaka su velike. Kvalitetno zastupanje u svim sudskim postupcima, uključujući upravni spor, omogućava strankama da izbjegnu nepotrebna „lutanja“ u pravnim prostranstvima. Stranke često nisu upoznate s posebnostima postupaka u kojima su se našle te opunomoćenici u tim situacijama mogu uvelike pomoći. Kvalitetni opunomoćenici, upoznat će stranku sa svim specifičnostima situacije u kojoj se nalazi, a ponajprije će ju poučiti o pravima koja ima u sporu, ali i njezinim dužnostima.

Nastavljajući se na navedene primjedbe autori ističu nekoliko činjenica o odvjetnicima kao opunomoćenicima stranaka. U potpunosti se slažu s Uzelcem kada problematizira kvalifikacije odvjetnika kao opunomoćenika, odnosno kada pojašnjava zašto odvjetnici ne moraju nužno biti najbolji zastupnici stranke. Tako u prvom redu ističe da odvjetnici nisu jedini kvalificirani za zastupanje jer se kvalifikacija za zastupanje ,izvodi iz formalnog obrazovanja, iskustva, posebnih osobnih odlika, stručne licence ili posebnog statusa nositelja - alternativno, kumulativno ili u raznim mješovitim varijantama“. Nadalje, navodi da su u različitim poredbenim sustavima različiti i zahtjevi koji se postavljaju pred osobe opunomoćenika, odnosno da odvjetničko svojstvo nije nužno niti dostatno svojstvo. I konačno, nisu svi predmeti iste složenosti, neki su kompleksni, traže visoko specijalizirano znanje, dok drugi

Zaključuje da procesno pravo ne može biti ravnodušno prema situacijama u kojima se procesna ravnoteža narušava zbog nesposobnosti jedne strane da se učinkovito zastupa u parnici. Uzelac, Obvezatno odvjetničko zastupanje? Prilog diskusiji o reformi hrvatskog parničnog prava. Teorijski i komparativni aspekti, 154.

63 O strukturi upravnih sudova, v. primjerice na mrežnoj stranici sudova Estonije, pristup 27. studenoga 2019., https:/www.kohus.ee/en/estonian-court-system/administrative-courts, a o učinkovitosti sudstva v. u studiji čiji su rezultati objavljeni na mrežnoj stranici: https://news.err. ee/837471/study-estonian-judicial-system-among-most-efficient-in-eu, pristup 27. studenoga 2019 . 
traže neke općenite značajke koje ima svaki pravnik, a treći općenito razborito i logično razmišljanje. U tom smislu, Uzelac navodi da nisu svi odvjetnici jednako kvalificirani za zastupanje u svim slučajevima. ${ }^{64}$

Autori navode i još jedan, u praktičnom pravnom životu vrlo važan, argument koji dovodi u pitanje mogući monopol zastupanja odvjetnika kao opunomoćenika u upravnom sporu. On se odnosi na univerzalnost, odnosno na lokalizaciju zastupanja. Ističe se, naime, kako odvjetnici koji profesionalno nastupaju pred određenim sudom poznaju iz vlastitog iskustva i pravo i običaje i praksu, koji vrijedi na određenom području. Poznaju, što je iznimno važno, i socijalne odnose na sudu, kvalitetu sudaca koji sude na lokalnim sudovima, ali i kvalitetu administrativnog i drugog osoblja sudova - imaju, dakle, vrlo jasan uvid u zbiljsko društveno i životno funkcioniranje suda. ${ }^{65}$ Isključivo angažiranje odvjetnika kao opunomoćenika u upravnom sporu ne može se opravdati lokalizacijom zastupanja. Upravno je sudovanje u Republici Hrvatskoj dvostupanjsko, ${ }^{66}$ ali su prvostupanjski upravni sudovi razmješteni po vrlo širokom regionalnom principu - ima ih samo četiri i ne slijede, dakle, niti teritorijalnu logiku razmještaja županijskih građanskih sudova, a kamoli logiku općinskih sudova. Razmješteni su, prema tome, vrlo univerzalistički pa je pogrešno pretpostaviti da će tužitelji koji kao opunomoćenike angažiraju odvjetnike imati ikakve praktične koristi zbog činjenice da je profesionalna djelatnost odvjetnika primarno povezana $\mathrm{s}$ određenim područjem.

\section{POREZNI SAVJETNICI KAO OPUNOMOĆENICI U UPRAVNOM SPORU?}

S obzirom na to da je Visoki upravni sud Rješenjem 5 UsI-730/13-5 od 16. siječnja 2015. zauzeo stajalište prema kojem porezni savjetnici ne mogu u upravnom sporu sudjelovati u svojstvu opunomoćenika tužitelja autori smatraju potrebnim iznijeti razmišljanja upravo o poreznim savjetnicima kao mogućim opunomoćenicima u upravnom sporu.

Zakon o poreznom savjetništvu ${ }^{67} \mathrm{u}$ čl. 2. st. 1. određuje da je porezno savjetništvo djelatnost kojom se u skladu s pravnim, gospodarstvenim, poreznim i računovodstvenim sustavom Republike Hrvatske, osigurava na pouzdan način pravilna primjena poreznih propisa od poreznih obveznika. Prema tome, temeljni su ciljevi poreznoga savjetništva kao djelatnosti sljedeći: javnopravni - osiguravanje pravilne primjene poreznih propisa od strane poreznih obveznika, ali i privatnopravni

64 Uzelac, Obvezatno odvjetničko zastupanje? Prilog diskusiji o reformi hrvatskog parničnog prava. Teorijski i komparativni aspekti, 156-157.

65 V. o navedenom u Uzelac, Obvezatno odvjetničko zastupanje? Prilog diskusiji o reformi hrvatskog parničnog prava. Teorijski i komparativni aspekti, str. 14. Uzelac navodi kako se i povijesno odvjetništvo razvilo spajanjem funkcije sudskog službenika koji predstavlja predmet sudu (advocatus) i privatnog savjetnika ili tutora stranke (procurator).

66 Prvostupanjski upravni sudovi nalaze se u Osijeku, Rijeci, Splitu i Zagrebu, a drugostupanjski Visoki upravni sud nalazi se u Zagrebu.

67 Zakon o poreznom savjetništvu, Narodne novine, br. 127/00., 76/13., 115/16. (u nastavku rada: ZPS). 
- jer se pravilnom primjenom poreznih propisa porezni obveznici štite od mogućih negativnih posljedica koje bi pogrešna primjena propisa za njih mogla imati.

ZPS nadalje, razrađujući navedene ciljeve propisuje, između ostalog, u čl. 2. st. 2. da je porezno savjetništvo i djelatnost zastupanja u svim poreznim i prekršajnim postupcima pred poreznim tijelima, sudjelovanja u poreznim upravnim sporovima $\mathrm{i}$ vještačenja po odluci suda i/ili poreznog tijela u poreznim predmetima.

Zakonodavac je, prema tome, očito ostvarivanje svrhe poreznog savjetništva želio osigurati i u upravnom postupku i u upravnom sporu. Navedena je želja zakonodavca potpuno ispravna i logična - upravni postupak i upravni spor, iako odvojeni, ipak su dvije čvrsto povezane cjeline. Očita je, nadalje, i želja zakonodavca da porezno savjetništvo obuhvati i široke aspekte sudjelovanja ${ }^{68}$ poreznih savjetnika u upravnom postupku i upravnom sporu - i zastupanje stranaka, ali i vještačenje.

Porezni savjetnici moraju biti ili pravne ili ekonomske struke, moraju imati pet ili sedam godina radnog iskustva na poreznim poslovima (ovisno o stručnoj spremi) ${ }^{69}$ te moraju položiti ispit za poreznog savjetnika koji, između brojnih predmeta ekonomske, financijske i pravne struke, uključuje i polaganje materije ZUP-a i ZUSa. ${ }^{70}$

Već je ranije istaknuto kako upravni spor odlikuju brojne posebnosti koje ga oštro razlikuju od ostalih pravnih postupaka, pa, prema tome, i od parničnog postupka. Tako iz cjelokupne zakonske regulacije proizlazi kako je cilj ZUS-a zaštititi subjektivna prava fizičkih i pravnih osoba, kao i objektivnu zakonitost. Pritom se naglašava kako je u prvom planu zaštita subjektivne, a tek podredno objektivne zakonitosti. Nadalje, naveli smo kako i samo zakonsko uređenje parničnog postupka u ZPP-u (iako prilično restriktivno) ipak ostavlja mogućnost da stranku u parničnim postupcima zastupaju i osobe koje nisu odvjetnici, a pogotovo je prema takvoj mogućnosti otvorena teorija građansko-procesnog prava. Također, autori napominju kako upravni spor karakterizira dvostupanjska organizacija, koncipirana po vrlo širokom regionalnom

68 Autori smatraju kako porezni savjetnici mogu sudjelovati u upravnom sporu u svim ulogama koje im omogućuju ZUS i ZPS: zakonskih zastupnika, vještaka i opunomoćenika (što ćemo podrobnije objasniti u nastavku rada). Mislimo, naime, kako je pojam ,sudjelovanje u poreznim upravnim sporovima“ širi pojam koji uključuje sve navedene uloge poreznih savjetnika u upravom sporu (što znači da se njime nikako nije željelo isključiti porezne savjetnike od mogućnosti sudjelovanja u upravnom sporu u svojstvu opunomoćenika). Ovakvo naše stajalište svakako potvrđuje i sudska praksa koja je poreznim savjetnicima omogućavala zastupanje stranka u svojstvu opunomoćenika sve do stupanja na snagu spomenutih novela ZUS-a iz 2014. Pojam „sudjelovanje u poreznim upravnim sporovima“ ZPS, naime koristi od svojega prvotnog teksta iz 2000.

69 V. čl. 9. ZPS-a.

70 Ispit za poreznog savjetnika detaljno je uređen Pravilnikom o postupku i uvjetima polaganja ispita za poreznog savjetnika i Programom polaganja ispita za poreznog savjetnika, koje je donijela Skupština Komore poreznih savjetnika 16. prosinca 2016. Detaljnije v. na: http://hkps. $\mathrm{hr} / 2016 / 08 / 26 /$ popis-ispitne-literature/, pristup 19. studenoga 2019. Porezni savjetnik, odnosno osoba koja želi postati porezni savjetnik treba položiti sljedeće predmete: Osnove poreznog sustava, porezne politike i financijsko izravnanje, Porezno pravo u Republici Hrvatskoj, Porez na dobit, Porez na dohodak i doprinosi, Neizravne poreze i carine, Računovodstvo, financijske izvještaje i reviziju, Osnove financijskog sustava Republike Hrvatske, Pravo trgovačkih društava te Subjekte porezno-pravnog odnosa (ostali). 
principu.

Slijedom svega navedenoga autori iznose razloge zbog kojih smatraju da se poreznim savjetnicima mora (ponovno) dopustiti zastupanje stranaka u upravnom sporu u svojstvu opunomoćenika.

Ponajprije, u promišljanju o ulozi poreznih savjetnika u upravnom sporu trebamo polaziti od javnopravne i privatnopravne svrhe njihova djelovanja, kao i od svrhe upravnog spora koja je i zaštita subjektivne, ali i zaštita objektivne zakonitosti. Zakonodavac je propisivanjem mogućnosti sudjelovanja poreznih savjetnika u upravnom sporu želio osigurati upravo navedene svrhe - osigurati pravnu zaštitu građana u situacijama kada su djelovanjem poreznih javnopravnih tijela povrijeđena prava, ali i osigurati i opću zakonitost i pravilnost rješavanja i postupanja u poreznim upravnopravnim predmetima.

Porezne upravne stvari često su vrlo visokog stupnja stručne složenosti čije rješavanje zahtijeva poznavanje specifičnih nepravnih područja - financija, računovodstva i sl. Porezni su savjetnici svojim obrazovanjem i užom specijalizacijom svakako potpuno kvalificirani pružati usluge zastupanja stranaka u tom području upravo zbog vrlo dobrog poznavanja navedenih područja.

Porezni savjetnici, upravo zbog navedenih kvalifikacija, nesporno i mogu u svojstvu opunomoćenika zastupati stranke u upravnim postupcima. Mišljenje autora je da nema nikakvog razloga uskratiti im takvu mogućnost u upravnom sporu. Činjenica da su bili opunomoćenici stranaka u poreznim upravnim postupcima, koji prethode vođenju upravnog spora, znači i da su iznimno dobro upoznati s konkretnim poreznim predmetima o kojima se odlučuje u upravnom sporu. Isključiti ih od mogućnosti zastupanja u svojstvu opunomoćenika u upravnom sporu te takvu ulogu potencijalno dodijeliti nekom drugom (odvjetniku) može značiti i uskratiti strankama da ih zastupaju osobe koje su najbolje upoznate s njihovim predmetima.

\section{ZAKLJUČAK}

Zakvalitetno zastupanje, nužnoje daje osoba opunomoćenika doista osposobljena za zastupanje u predmetu koji se vodi pred upravnim sudom. Opunomoćenik koji je kvalificiran za određenu materiju, bilo da je odvjetnik ili stručnjak u svom području, poboljšava kvalitetu sudovanja u cjelini, pridonosi ekonomičnosti postupka, odnosno ubrzava ga, ali ne pod cijenu da se našteti utvrđivanju materijalne istine. Uzelac vidi koristi kvalitetnoga zastupanja u tome što se zaobilaze nesporazumi, neracionalne radnje neobrazovanih stranaka, rasterećuje se pravosuđe, omogućuje se koncentracija na stvarno sporne situacije te se poboljšava opća razina sudovanja. ${ }^{71}$

Kvalificirani opunomoćenik će lakše uočiti nepravilnosti u postupku, što je posebno važno u materiji upravnog prava. Niz postupovnih zakona propisuje različite rokove u kojima se mogu poduzimati pojedine radnje ili izjavljivati redovne i izvanredne pravne lijekove, ali i niz drugih osobitosti koje zahtijevaju izvrsno snalaženje u često kompleksnim pitanjima koja uključuju brojne sudionike, različita

71 V. Uzelac, Obvezatno odvjetničko zastupanje? Prilog diskusiji o reformi hrvatskog parničnog prava. Teorijski i komparativni aspekti, 156. 
javnopravna tijela kao što su primjerice situacije gdje se odluka donosi na temelju potvrde ili suglasnosti, odobrenja ili mišljenja drugoga javnopravnog tijela itd.

Upravno je pravo iznimno opsežno, obuhvaća raznolike i često potpuno različite upravne oblasti te je vrlo teško pretpostaviti da je moguća ikakva generalna specijalizacija za materiju upravnog prava koja bi uključivala i dublje poznavanje svih tih posebnih upravnih oblasti.

Stoga autori smatraju da je zauzeta previše ograničavajuća praksa u tumačenje odredbe čl. 21. st. 2. ZUS-a koja propisuje odgovarajuću primjenu odredbi parničnog postupka u materiji zastupanja u upravnom sporu.

Dakako, svi argumenti navedeni u radu nikako ne znače da autori smatraju kako u svim upravnim stvarima pred upravnim sudovima kao opunomoćenici stranaka moraju nastupati osobe čija stručno tehnička znanja prevladavaju nad poznavanjem prava. Određeni broj upravnih stvari iz vrlo stručnih i tehničkih područja (pa tako i iz domene poreznih upravnih stvari) može biti većeg stupnja čisto pravne složenosti (bilo postupovnopravne, bilo materijalnopravne) te u tom slučaju uslugu zastupanja u svojstvu opunomoćenika mogu bolje obavljati odvjetnici.

Autori su u radu željeli obrazložiti zbog čega smatraju da usluge zastupanja u svojstvu opunomoćenika u upravnim sporovima treba omogućiti širem krugu osoba, a ne zauzimati restriktivni pristup. Najjednostavnije rečeno je da se time omogućava kvalitetnija pravna zaštita građana u svim upravnim stvarima, a ujedno i kvalitetnija zaštita objektivne zakonitosti.

Konačni izbor osobe koja će je u svojstvu opunomoćenika zastupati u upravnim sporovima i tako, prema načelima stranačke autonomije i dispozitivnosti, ovisi o strankama. One moraju moći birati tko će najbolje zastupati njihove interese. ${ }^{72}$ Dakako, da bi im se omogućila realizacija spomenutih načela, najprije im se mora ponuditi mogućnost izbora.

Nažalost, pravna je praksa takvu mogućnost izbora uskratila te bogatiji i kvalitetniji sustav zastupanja zamijenila siromašnijim i manje kvalitetnim. Autori se nadaju da će rad potaknuti i same suce upravnih sudova i zakonodavca, da obrate pozornost na važnost kvalitetnoga zastupanja u upravnom sporu te da pronađu načine koji će omogućiti da građane, tužitelje u upravnom sporu, zastupaju upravo one osobe koje svojim stručnim znanjem najbolje znaju štititi prava i interese stranaka, ali i objektivnu zakonitost.

72 Veliki dio odgovornosti svakako je i na strani potencijalnih zastupnika stranaka. Profesionalna etika trebala bi nalagati da se uvijek uputi na onu osobu koja bi najbolje mogla zastupati stranku i brinuti se o njezinim interesima u konkretnoj upravnoj stvari. Tako bi, npr. porezni savjetnik koji bi ocijenio da će stranku u konkretnoj stvari bolje zastupati odvjetnik, jer u njoj prevladavaju čisto pravna pitanja, stranku zaista i trebao uputiti na odvjetnika. Isti bi princip trebao vrijediti i za odvjetnike koji procijene da u konkretnoj stvari prevladavaju ekonomska ili financijsko-računovodstvena pitanja. 


\section{LITERATURA}

Knjige i članci:

1. Administrative Justice in Estonia - Report for Estonia, 1. Pristup 9. prosinca 2019. http:// www.aca-europe.eu/en/eurtour/i/countries/estonia/estonia_en.pdf

2. Andersen, Jakob Skaadstrup. „Denmark“. U: Tax Disputes and Litigation Review, ed. Simon Whithead, 62-69. London: Law Business Research, 2019.

3. Androulakis, Vassilis. Administrative Justice in Europe - Greek Report. Pristup 28. studenoga 2019. http://www.aca-europe.eu/en/eurtour/i/countries/greece/greece_en.pdf

4. Britvić Vetma, Bosiljka. „Ustroj i nadležnost upravnih sudova“. Zbornik Pravnogfakulteta Sveučilišta u Rijeci 33, br. 1, (2012): 389-412.

5. Busching, Thomas. Tax Controversy in Germany. Pristup 21. studenoga 2019. https:// www.lexology.com/library/detail.aspx?g=0cda47f8-d6f0-458b-b459-e662d797fc93

6. Colin, Frédéric i Marie-Laure Messe. L'essentiel du contentieux administratif. Pariz: Gaulino, 2014.

7. Cordewener, Axel i Michael Hendricks „Germany“. U: Tax Disputes and Litigation Review, ed. Simon Whithead, 101-115. London: Law Business Research, 2019.

8. Crnković, Mateja. „Objektivni upravni spor u hrvatskom i poredbenom pravu“. Zagreb: Pravni fakultet Sveučilišta u Zagrebu, 2015.

9. Derouin, Philippe. „France“. U: Tax Disputes and Litigation Review, ed. Simon Whithead, 89-100. London: Law Business Research, 2019.

10. Docclo, Caroline P. „Belgium“. U: Tax Disputes and Litigation Review, ed. Simon Whithead, 15-30. London: Law Business Research, 2019.

11. Đerđa, Dario i Marko Šikić. Komentar Zakona o upravnim sporovima uz uvodni članak Dragana Medvedovića Novi sustav upravnog sudovanja. Zagreb: Novi informator, 2012.

12. Flavier, Hugo i Charles Forger. „Administrative justice in France. Between singularity and classicism“. Brics Law Journal 3, br. 2 (2016): 80-111.

13. Gjidara, Marc. „Državni savjet u francuskom pravnom sustavu“. U: Zbornik radova Hrvatsko-francuskog pravnog simpozija, ur. Damir Aviani, 8-9, Split: Sveučilište u Splitu, 2007.

14. Held, Henrik-Riko. „Procuratoris revocatio u pravu Tripartita “. Zbornik Pravnog fakulteta u Zagrebu 68, br. 5-6 (2018.): 825-852.

15. Held, Mateja. „Neka važna pitanja uređenja i reformi upravnog sudovanja u europskim zemljama“. Zbornik Pravnog fakulteta u Zagrebu 69, br. 4 (2019): 553-587.

16. Horvat, Marijan. Rimsko pravo. Zagreb: Pravni fakultet, 2002.

17. Köhler, Martin. „The Reform of The Administrative Jurisdiction in Austria - Theoretical Background and Main Features od The System“. Public Security and Public Order 14, br. 4 (2015): 31-63.

18. Kraan, Paul. „Netherlands“. U: Tax Disputes and Litigation Review, ed. Simon Whithead, 207-218. London: Law Business Research, 2019.

19. Luczak Slawomir i Karolina Gotfryd. „Poland“. U: Tax Disputes and Litigation Review, ed. Simon Whithead, 260-274. London: Law Business Research, 2019.

20. Maganić, Aleksandra i Dario Đerđa. Primjena odredbi parničnog postupka u upravnom sporu. Zagreb: Pravosudna akademija, 2017.

21. Rostaš Beroš, Lidija. „Zastupanje stranke u upravnom sporu“, Zbornik Pravnog fakulteta Sveučilišta u Rijeci 37, br. 1 (2016): 735-751.

22. Sauvé, Jean-Marc. „Rad i utjecaj francuskog Državnog savjeta“. Zbornik radova Pravnog fakulteta u Splitu 45, br. 1 (2008): 1-9.

23. Schanchner, Gerald, Kornelia Wittmann i Nicolas D. Wolski. „Austria“. U: Tax Disputes and Litigation Review, ed. Simon Whithead, 6-14. London: Law Business Research, 2019.

24. Stavropoulus, Ioannis. „Greece“. U: Tax Disputes and Litigation Review, ed. Simon Whithead, 116-126. London: Law Business Research, 2019. 
25. Stelzer, Manfred. Constitution of the Republic of Austria: A Contextual Analysis. Oxford and Portland, Oregon: Hart Publishing, 2011.

26. Triva, Siniša. Rječnik Građanskog procesnog prava. Zagreb: Informator, 1968.

27. Triva, Siniša, Velimir Belajec i Mihajlo Dika, Građansko parnično procesno pravo. Zagreb: Narodne novine, 1986.

28. Uzelac, Alan. „Obvezatno odvjetničko zastupanje? Prilog diskusiji o reformi hrvatskog parničnog prava. Teorijski i komparativni aspekti, Pravo u gospodarstvu 37 (1998): 149185.

29. Weckström, Jouni. „Finland“. U: Tax Disputes and Litigation Review, ed. Simon Whithead, 77-88. London: Law Business Research, 2019.

Propisi:

1. Austrija, Verwaltungsgerichtshofgesetz 1985, BGBl. Nr. 10/1985, BGBl. I Nr. 194/1999, BGB1. I Nr. 104/2019.

2. Estonija, Zakon o postupku pred upravnim sudom, 2012.

3. Finska, Administrative Judicial Procedure Act, 586/1996; s izmjenama 891/2015.

4. Francuska, Décret $n^{\circ}$ 53-934 du 30 septembre 1953 portant réforme du contentieux administratif, Journaux Officiels de la République Française (JORF) od 1. listopada 1953.

5. Hrvatska, Pravilnik o postupku i uvjetima polaganja ispita za poreznog savjetnika od 16. prosinca 2016.

6. Hrvatska, Program polaganja ispita za poreznog savjetnika od 16. prosinca 2016

7. Hrvatska, Zakon o odvjetništvu, Narodne novine, br. 09/94., 117/08., 50/09., 75/09., $18 / 11$.

8. Hrvatska, Zakon o parničnom postupku, Narodne novine, br. 53/91., 91/92., 58/93., 112/99., 88/01., 117/03., 88/05., 02/07., 84/08., 96/08., 123/08., 57/11., 148/11., 25/13., 89/14., 70/19.

9. Hrvatska, Zakon o poreznom savjetništvu, Narodne novine, br. 127/00., 76/13., 115/16.

10. Hrvatska, Zakon o upravnim sporovima, Narodne novine, br. 20/10., 143/12., 152/14. i 29/17.

11. Njemačka, Verwaltungsgerichtsordnung od 21. siječnja 1960. u verziji objavljenoj u ožujku 1991. (BGBl. I S. 686), sa zadnjom izmjenom od 12. srpnja 2018. (BGB1. I S. 1151)

Sudska praksa:

1. Odluka i Rješenje Ustavnog suda Republike Hrvatske, U-I-2573/2012 od 27. rujna 2016.

2. Odluka Ustavnog suda Republike Hrvatske, U-III/1/2009 od 3. studenog 2010.

3. Rješenje Visokog upravnog suda Republike Hrvatske, Usž-76/15-2 od 26. veljače 2015.

\section{Mrežni izvori}

1. Hrvatska komora poreznih savjetnika. Pristup 28. studenoga 2019. http://hkps.hr

2. Savezni financijski sud Savezne Republike Njemačke. Pristup 21. studenoga 2019. https:// www.bundesfinanzhof.de/content/information-english?tid $=42$

3. Savezni upravni sud Savezne Republike Njemačke. Pristup 2. prosinca 2019. https://www.bverwg.de/en/rechtsprechung/verwaltungsgerichtsbarkeit/aufbau-derverwaltungsgerichtsbarkeit

4. Službena stranica upravnih sudova Estonije. Pristup 27. studenoga 2019. https://www. kohus.ee/en/estonian-court-system/administrative-courts

5. Vodič kroz sudove Estonije. Pristup 22. studenoga 2019. https://www.lawyersestonia. com/a-guide-to-estonian-courts

6. Vrhovni sud Republike Hrvatske - praksa sudova. Pristup 20. studenoga 2019. https:// sudskapraksa.csp.vsrh.hr 


\section{Marko Šikić* \\ Mateja Held**}

Summary

\section{AUTHORISED REPRESENTATIVES IN ADMINISTRATIVE DISPUTES}

Amendments to the Act on Administrative Disputes 2014 added paragraph 2 to the Article 21. It refers to the proper application of the provisions of the Civil Procedure Act in administrative disputes. The Croatian administrative courts have taken a restrictive approach in interpreting that provision, which excludes certain categories of persons from representing complainants and interested parties. The paper problematizes the concept of the authorised representatives in administrative disputes and emphasizes expertise and quality as important features of the representation in general, including the authorised representatives in administrative disputes. The comparative arrangements of European systems in the subject matter are also analysed. It is argued that when interpreting the representation provisions, it is necessary to consider the particularities of the administrative dispute, but also the formulation of the provision, which undoubtedly leaves room for interpretation, as it refers to the "appropriate" application of the provision governing representation in civil proceedings.

Keywords: administrative disputes; party; representation; representative; tax adviser.

\section{Zusammenfassung}

\section{BEVOLLMÄCHTIGTER IM VERWALTUNGSRECHT}

Nach der Erlassung der Novelle des Gesetzes über Verwaltungsstreitigkeiten in 2014, durch welche man in der Verwaltungsstreitigkeit durch Absatz 2 im Art. 21 auf entsprechende Anwendung der Bestimmungen der Zivilprozessordnung hinweist, haben kroatische Verwaltungsgerichte eine restriktive Position über die Auslegung dieser Bestimmung, laut welcher manchen Kategorien die Vertretung vom Kläger und der interessierten Person verwehrt ist, eingenommen. In diesem Beitrag problematisiert man den Begriff des Bevollmächtigten und betont die Sachkenntnisse und Qualität

* Marko Šikić, Ph.D., Full Professor, Faculty of Law, University of Zagreb; marko.sikic@pravo. hr.

** Mateja Held, Ph.D., Assistant Professor, Faculty of Law, University of Zagreb; mateja.held@ pravo.hr. 
als wichtige Eigenschaften des Bevollmächtigten im Allgemeinen und insbesondere des Bevollmächtigten in der Verwaltungsstreitigkeit. Diesbezüglich analysiert man im Beitrag auch rechtsvergleichende Regelungen europäischer Systeme. Es wird die Stellung genommen, dass man bei der Auslegung der Bestimmungen über Vertretung sowohl der Besonderheiten der Verwaltungsstreitigkeit als auch der Formulierung der Bestimmung selbst Rechnung tragen muss, weil diese Formulierung auf „entsprechende“ Anwendung der im Zivilprozess anwendbaren Bestimmung über Vertretung hinweist.

Schlüsselwörter: Verwaltungsstreitigkeit; Partei; Vertretung; Bevollmächtigter; Steuerberater.

Riassunto

\section{RAPPRESENTANTI NEL CONTENZIOSO AMMINISTRATIVO}

In seguito all'emendamento della Legge sui contenziosi amministrativi del 2014 con il quale è stato aggiunto il secondo comma all'art. 21 con il quale si fa richiamo all'applicazione nel contenzioso amministrativo delle disposizioni della Legge sul processo civile, le corti amministrative croate hanno optato per un'interpretazione restrittiva di questa disposizione in base alla quale sono determinate le categorie escluse dalla possibilità di rappresentare il ricorrente e la persona interessata. Nel lavoro si problematizza la nozione di rappresentante e si evidenziano la competenza e la qualità come caratteristiche importanti come del rappresentante in generale, così anche del rappresentante nel contenzioso amministrativo. Nel lavoro si analizza in ottica comparatistica anche la disciplina di altri sistemi europei in questa materia. S'è dell'opinione che in occasione dell'interpretazione delle disposizioni sulla rappresentazione è necessario tenere conto delle specificità del contenzioso amministrativo, ma pure della formulazione della disposizione con la quale si lascia indubitabilmente la possibilità d'interpretazione perché si istruisce "all'appropriata" applicazione della disposizione con la quale è regolata la rappresentazione nel processo civile.

Parole chiave: contenzioso amministrativo; parte; rappresentazione; rappresentante; consulente fiscale. 
